\title{
Statyba
}

\section{A NEW STRESS-STRAIN RELATIONSHIP FOR CRACKED TENSILE CONCRETE IN FLEXURE}

\section{G. Kaklauskas PhD}

To cite this article: G. Kaklauskas PhD (1999) A NEW STRESS-STRAIN RELATIONSHIP FOR CRACKED TENSILE CONCRETE IN FLEXURE, Statyba, 5:6, 349-356, DOI:

10.1080/13921525.1999.10531489

To link to this article: https://doi.org/10.1080/13921525.1999.10531489

曲 Published online: 26 Jul 2012.

Submit your article to this journal

III Article views: 2414 


\section{A NEW STRESS-STRAIN RELATIONSHIP FOR CRACKED TENSILE CONCRETE IN FLEXURE}

\section{G. Kaklauskas}

\section{Introduction}

At the end of the nineteenth century, in testing small mortar prisms reinforced with steel wires it has been observed [1] that their tensile load-deformation response was well above the bare steel bar response. In 1908, Mörsch [2] explained that cracked concrete has the ability to decrease strain in reinforcement due to tensile stresses in the concrete between the cracks. This phenomenon was later called tension stiffening. Sometimes tension stiffening is confused with tension softening [3]. The latter is a property of plain concrete, while tension stiffening is a property of reinforced concrete. Due to bond with reinforcement, the cracked concrete between cracks carries a certain amount of tensile force normal to the cracked plane. The concrete adheres to the reinforcement bars and contributes to overall stiffness of the structure. Bond behaviour is a key aspect since it controls the ability of reinforcement to transfer tensile stresses to concrete. In the real, discrete cracking the cracks are spaced at final distances and the concrete between cracks interacts with the embedded steel bars. The stresses in the bars are highest in the cracks and decrease in the direction from the crack space. The stress distribution in a bar embedded in concrete with more or less regularly spaced cracks resembles a periodic function with peaks in the cracks and minimums between the cracks.

Based on a variety of assumptions, many constitutive models for reinforced concrete in tension have been proposed [4-15].

In approach based on experimental results, average stress-strain relationships for concrete in tension have been defined from several types of tests of reinforced concrete members subjected to tension, eg $[8,15,16]$. Tensile concrete behaviour in reinforced concrete has been often modelled by a relationship shown in Fig 1 . An ascending straight line with a slope of $E_{c}$, concrete mo- dulus of elasticity, reaching the tensile strength, $\sigma_{c r}$, models behaviour of non-cracked concrete. Its descending part models tension stiffening effect and is characterised by parameters $\alpha$ and $\beta$ which are related to tensile strength, $\sigma_{c r}$, and the corresponding strain $\varepsilon_{c r}$ respectively. Scanlon and Murray [17] used a saw-toothed and Lin and Scordelis [18] a curved diagram for the descending branch. Vebo and Ghali [19] used a trilinear piecewise stress-strain relationship for concrete in tension. Although tension stiffening is most frequently assigned to the concrete, however, it can be handled by a change in the modulus assigned to the steel [6].

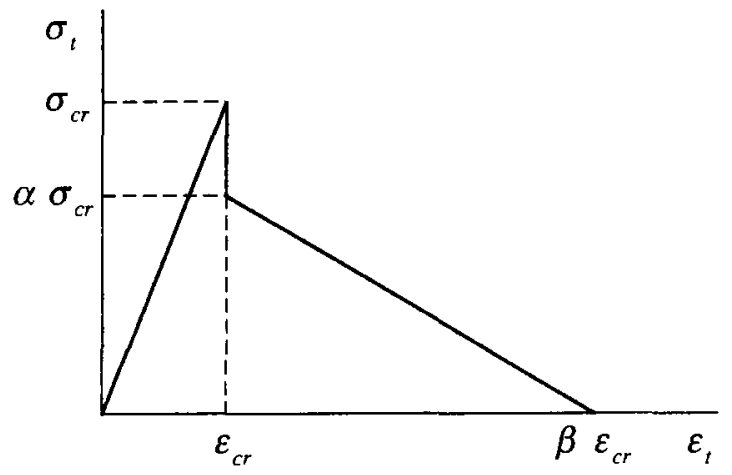

Fig 1. Average stress-strain relationship for concrete in tension

Different fixed values of parameter $\beta$ which controls the tension stiffening have been specified by different investigators. Lin and Scordelis [18], Scanlon and Murray [17], Gilbert and Warner [6] adopted a value of 10. Damjanic and Owen [20] proposed values of 5 to 10 for shear-type cracking and 20 to 25 for flexural cracking. Mehlhorn [21] and Cope [22] used $\beta$ values which fall into the interval indicated above.

Based on experimental investigation of reinforced concrete panels subjected to pure shear Vecchio and Collins [8] proposed the following relationship for the cracked concrete: 


$$
\sigma_{t}=\frac{\sigma_{c r}}{1+\sqrt{200 \varepsilon_{t}}}
$$

where $\varepsilon_{t}$ is strain of tensile concrete.

This relationship was obtained from relatively heavily reinforced specimens, with a reinforcement percentage of $1.9 \%$ in at least one direction. Assessed $\beta$ for $\mathrm{Eq}$ (1) is about 20.

Carreira and Chu [23] proposed a relationship of the same general form as the stress-strain relationship in compression:

$$
\sigma_{t}=\frac{\beta_{t} f_{t}^{\prime}\left(\varepsilon_{t} / \varepsilon_{t}^{\prime}\right)}{\beta_{t}-1+\left(\varepsilon_{t} / \varepsilon_{t}^{\prime}\right)^{\beta_{t}}}
$$

where $\beta_{t}$ is an empirical factor.

An analysis has shown [24] that parameter $\beta$ has a great influence on numerical results particularly for lightly reinforced members. If to neglect tension stiffening in calculation of flexural members, deflections might be overestimated by 100 percent, particularly in the serviceability range of loads [6].

Accurate experimental investigations both on tensile $[25,26]$ and flexural $[5,27,28]$ reinforced concrete members have shown that tension stiffening is significantly affected by such factors as reinforcement ratio, bar diameter, concrete strength, cover, and the distribution of reinforcement.

An attempt was made by Prakhya and Morley [29] to include several parameters affecting the tension stiffening into the stress-strain curve of tensile concrete for analysis of flexural members. On the basis of simplified assumptions and by using some experimental data $[5,27]$ they have applied $\mathrm{Eq}$ (2) proposed by Carreira and Chu [23] by modifying the empirical factor $\beta_{t}$ :

$$
\beta_{t}=\left(\frac{100 A_{s}}{b\left(h-x_{n t}\right)}\right)^{0.366}\left(\frac{b\left(h-x_{n t}\right)}{n \pi c d_{b}}\right)^{0.344}\left(\frac{c}{s}\right)^{0.146},
$$

where $A_{s}$ is the cross-section area of tensile reinforcement; $b$ is the width; $h$ is the total depth; $c$ is the clear cover to the reinforcement; $d_{b}$ is the reinforcement bar diameter; $n$ is the number of bars; $s$ is the reinforcing spacing, and $x_{n t}$ is the neutral axis depth neglecting tension in the concrete.

The experimental data used for developing the constitutive model did not cover cases of small reinforcement ratios ( $p \geq 0.45 \%$ ) and for the number of variables included, the relationship lacks statistical justification. Besi- des, due to the simplified assumptions, the relationship "used in the layered approach will always underestimate the tension stiffening stresses" [29].

A number of tension stiffening models based on fracture mechanics principles has been proposed by Hilleborg [30], Sih and DiTommaso [31], Petersson and Gustavasson [32], Bažant and Oh [33], and Nallathambi et al [34]. Bažant and Oh [35] suggested a value of

$$
\beta=E_{c} / E_{t}+1(4),
$$

where the slope of the descending branch

$$
E_{t}=-\frac{0.483 E_{c}}{0.393+\sigma_{c r}}[\mathrm{MPa}]
$$

for practical values of $\sigma_{c r}$ giving $\beta$ between 5 and 8 .

Recently a method $[24,36,37]$ has been developed for determining the average concrete stress-strain relations in tension and compression from experimental moment-strain (curvature) diagrams of reinforced concrete beams. The stress-strain relations are computed incrementally from equilibrium equations for the extreme surface fibres. The computation is based on an idea of using the previously computed portions of the stress-strain relations at each load increment to compute the current increments of the stress-strain relations. The proposed method has been successfully applied [24] to accurately performed experimental data of Clark and Speirs [5]. Stressstrain relationships for tensile concrete were obtained for 14 beams with moderate reinforcement ratios.

Present research is dedicated to investigation of tension stiffening effect in lightly reinforced concrete beams using experimental data reported in literature. Average stress-strain relationships for cracked tensile concrete are derived for beams reinforced with plain and deformed bars. Based on these and previously obtained relationships [24] a new constitutive relationship for tensile concrete in flexure is proposed.

\section{Figarovskij test results in flexure}

Figarovskij [38] conducted experiments on lightly reinforced concrete beams with different reinforcement ratios using both plain and deformed bars. The experimental program was devoted to investigation of shortterm and long-term deformations and deflections of reinforced concrete beams. Present research deploys experimental data of the first and third series, ie rectangular cross-section specimens reinforced with plain and defor- 
med bars, respectively. The specimens were nominally $3.2 \mathrm{~m}$ long, $250 \mathrm{~mm}$ high and $180 \mathrm{~mm}$ wide and were tested under a four-point loading system which gave a constant moment zone and two shear spans of $1.0 \mathrm{~m}$ each. The measured cross-section dimensions and data on $100 \mathrm{~mm}$ concrete cube strength, $R_{10}$, and tensile steel yield strength as well as details on bottom reinforcement for each of the specimen are given in Table 1. The specimens were also reinforced with top reinforcement comprising of two $6 \mathrm{~mm}$ bars located at $15 \mathrm{~mm}$ from the top surface. Stirrups in the shear spans were provided to all the beams.

Tests of the beams were terminated prior to the yielding of reinforcement and the experimental results were presented in terms of moment-deflection, $(M-f)$, and moment-curvature, $(M-\kappa)$, diagrams for each of the specimen [38]. The latter were obtained from the average strain measurements taken in the zone of pure bending at two levels: the extreme compressive concrete surface and the centroid of tensile reinforcement.

Concrete tensile strength, $\sigma_{c r}$, and modulus of elasticity, $E_{c}$, necessary for analysis were determined from the following empirical formulae:

$$
\begin{gathered}
\sigma_{c r}=0.23 \sqrt[3]{R_{15}^{2}}[\mathrm{MPa}] \\
E_{c}=\frac{5.5 R_{15}}{27+R_{15}} \times 10^{4}[\mathrm{MPa}],
\end{gathered}
$$

where $R_{15}$ is $150 \mathrm{~mm}$ cube compression strength taken as a product of $R_{10}$ and conversion factor 0.91 .

\section{Derivation of stress-strain relationships for cracked tensile concrete in flexure}

This section presents results of derivation of stressstrain relationships for tensile concrete from the experimental $M-\kappa$ diagrams by the method proposed [24,36,37]. The experimental $M-\kappa$ diagrams are shown by dashed lines in Figs 2 and 3 for the first and third series respectively. For the purposes of analysis, the experimental moment-curvature diagrams were smoothed by MATLAB. Previous analysis [24] has shown that due to in some extent irregular distribution of experimental points, the smoothed $M-\kappa$ diagrams have slightly wavy form leading to a similar shape of the computed $\sigma_{t}-\varepsilon_{t}$ curve. In order to obtain smoothed shapes for the material $\sigma-\varepsilon$ diagrams, the experimental $M-\kappa$ curves have to

\begin{tabular}{|c|c|c|c|c|c|c|c|c|c|}
\hline \multirow{2}{*}{$\begin{array}{c}\text { Beam } \\
\text { No }\end{array}$} & \multirow{2}{*}{ Name } & \multirow{2}{*}{$\begin{array}{l}\text { Depth } \\
\text { [mm] }\end{array}$} & \multirow{2}{*}{$\begin{array}{l}\text { Width } \\
\text { [mm] }\end{array}$} & \multirow{2}{*}{$\begin{array}{l}\text { Effective } \\
\text { depth } \\
{[\mathrm{mm}]}\end{array}$} & \multirow{2}{*}{$\begin{array}{c}100 \mathrm{~mm} \text { cube } \\
\text { strength } \\
{[\mathrm{MPa}]}\end{array}$} & \multicolumn{3}{|c|}{ Tensile steel } & \multirow{2}{*}{$\begin{array}{c}\text { Reinforcement ratio } \\
{[\%]}\end{array}$} \\
\hline & & & & & & $\begin{array}{l}\text { Diameter } \\
{[\mathrm{mm}]}\end{array}$ & $\begin{array}{c}\text { Section } \\
\text { area } \\
\times 10^{-4}\left[\mathrm{~m}^{2}\right]\end{array}$ & $\begin{array}{c}\text { Yield } \\
\text { strength } \\
\text { [MPa] }\end{array}$ & \\
\hline \multicolumn{10}{|c|}{ Series I } \\
\hline 1 & P3-1Kk & 250 & 180 & 225 & 20.0 & 8 & 2.50 & 386 & 0.62 \\
\hline 2 & P3-2Kd & 249 & 181 & 224 & 30.5 & 8 & 2.50 & 384 & 0.62 \\
\hline 3 & $\mathrm{P} 2-2 \mathrm{Kd}$ & 250 & 180 & 225 & 21.0 & 8 & 2.00 & 374 & 0.49 \\
\hline 4 & $\mathrm{P} 2-1 \mathrm{Kk}$ & 249 & 179 & 225 & 20.0 & 8 & 2.00 & 386 & 0.50 \\
\hline 5 & P1-1Kk & 251 & 179 & 228 & 28.5 & 8 & 1.50 & 382 & 0.37 \\
\hline 6 & P1-2Kk & 250 & 180 & 227 & 28.5 & 8 & 1.50 & 382 & 0.37 \\
\hline \multicolumn{10}{|c|}{ Series III } \\
\hline 7 & P3-2Pd & 250 & 180 & 230 & 31.5 & 12 & 3.64 & 420 & 0.88 \\
\hline 8 & P3-1Pd & 250 & 180 & 230 & 31.5 & 12 & 3.64 & 420 & 0.88 \\
\hline 9 & P2-2Pk & 252 & 179 & 232 & 36.0 & 7.5 & 1.95 & 429 & 0.47 \\
\hline 10 & P3-1Pk & 250 & 180 & 229 & 21.0 & 7 & 2.36 & 519 & 0.57 \\
\hline 11 & P2-2Pd & 251 & 179 & 231 & 34.0 & 7.5 & 1.95 & 405 & 0.47 \\
\hline 12 & P2-1Pk & 249 & 180 & 225 & 22.0 & 7 & 1.69 & 519 & 0.42 \\
\hline 13 & P1-2Pk & 248 & 180 & 223 & 21.0 & 7 & 1.02 & 632 & 0.25 \\
\hline 14 & P1-1Pk & 249 & 180 & 223 & 22.0 & 7 & 1.02 & 632 & 0.25 \\
\hline 15 & $\mathrm{P} 0-2 \mathrm{Pk}$ & 251 & 179 & 229 & 34.0 & 7 & 0.676 & 487 & 0.16 \\
\hline 16 & P0-1Pk & 250 & 180 & 227 & 34.0 & 7 & 0.676 & 587 & 0.17 \\
\hline
\end{tabular}

Table 1. Main characteristics of specimens 
be averaged. The averaged curves were simply constructed from several characteristic experimental points. For most of the cases analysed, 5-8 experimental points were sufficient to obtain a numerically averaged curve which adequately represented all experimental points.

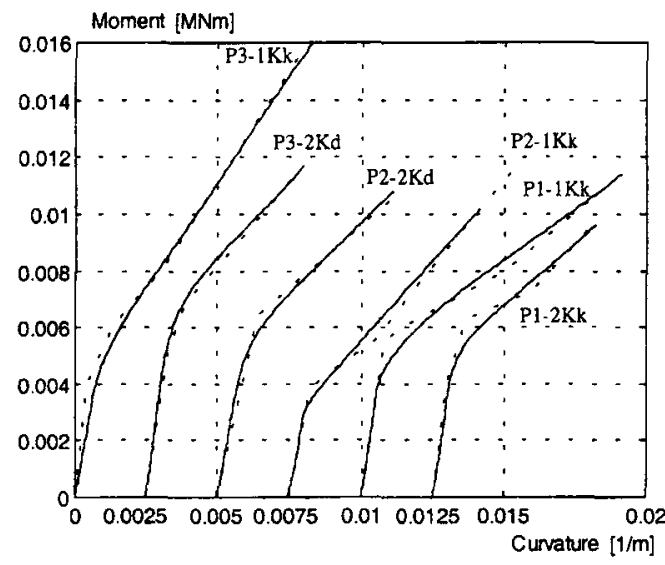

Fig 2. Experimental moment-curvature diagrams for beams of the first series .... measured — averaged and smoothed
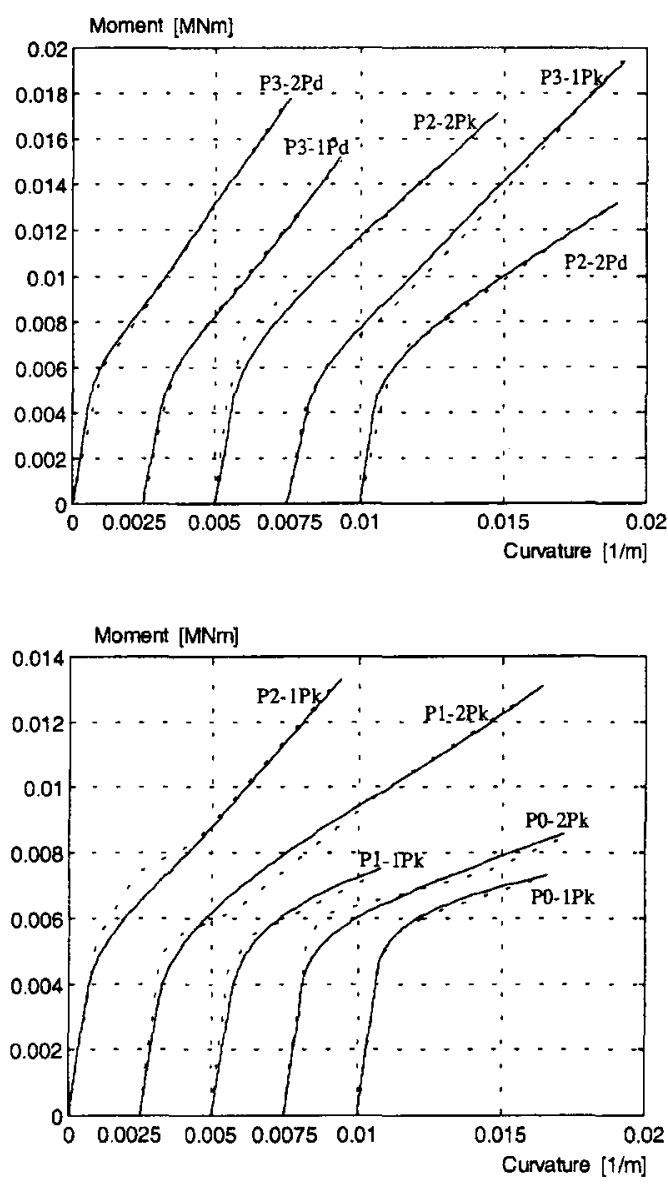

Fig 3. Experimental moment-curvature diagrams for beams of the third series - . - - measured _- averaged and smoothed
Averaged and smoothed $M-\kappa$ curves for the beams of the first and third series are shown by solid lines in Figs 2 and 3 respectively. The computed $\sigma_{t}-\varepsilon_{t}$ curves for these diagrams are shown in Figs 4 and 5.

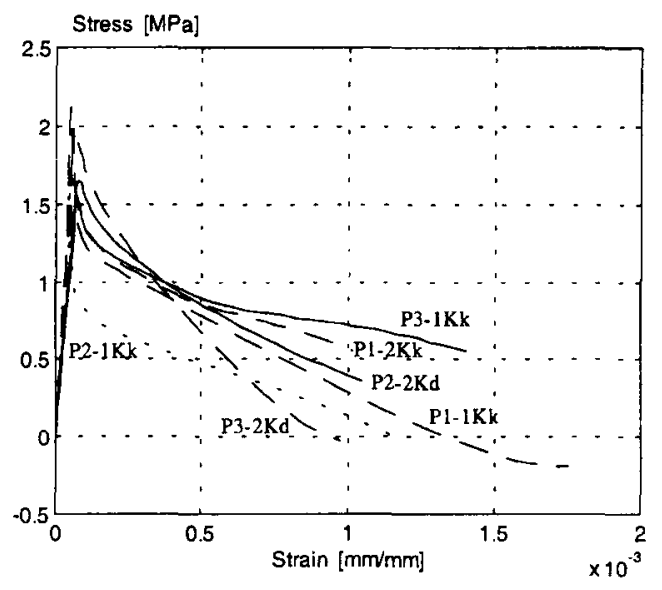

Fig 4. Computed $\sigma_{t}-\varepsilon_{t}$ curves for beams of the first series
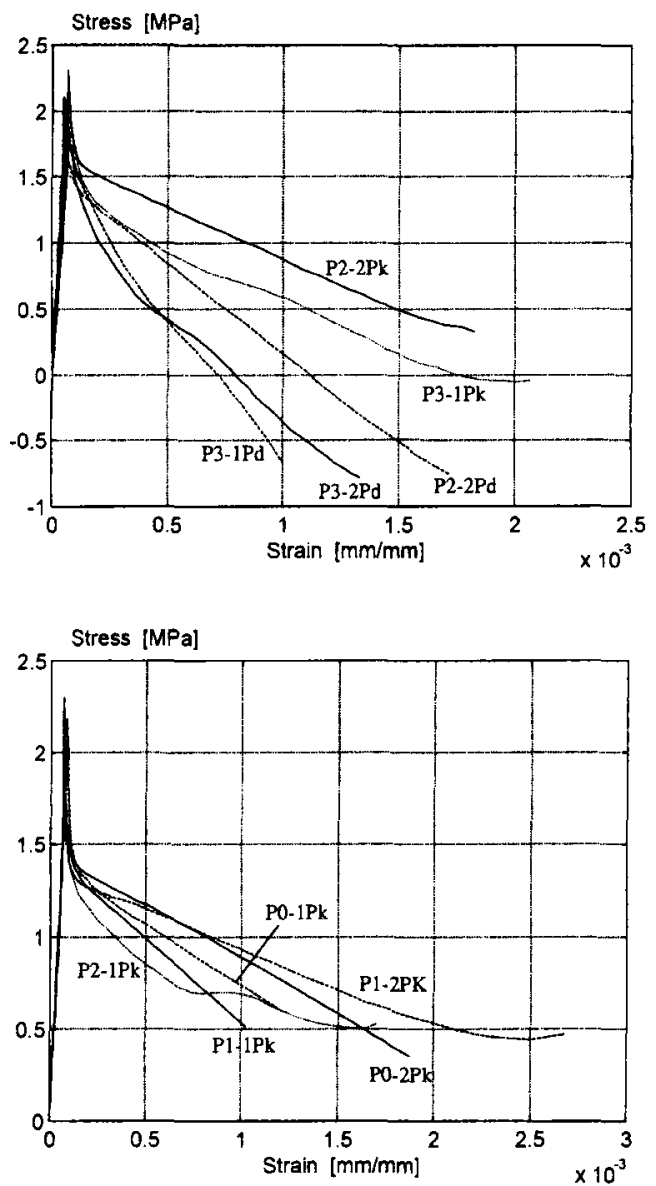

Fig 5. Computed $\sigma_{t}-\varepsilon_{t}$ curves for beams of the third series 
Although the curves shown in Figs 4 and 5 have quite a similar shape, the most striking is the difference in their extension length, which is characterised by strain $\varepsilon_{t, o}$ corresponding to zero stress. The present results in general support the previous findings [24] that strain $\varepsilon_{t, o}$ increases with decrease of reinforcement ratio $p$. Graphical presentation of this dependence taking $\varepsilon_{t, o}$ values in terms of parameter $\beta$ (Fig 1) is given in Fig 6, where signs " $x$ " and " + "correspond to data points of beams of the first series (plain bars) and data points of the third series (deformed bars) respectively. It must be said that some computed $\sigma_{t}-\varepsilon_{t}$ curves did not have the actual $\varepsilon_{t, o}$ strain corresponding to zero stress. Most often this was due to early termination of the test. For such beams imaginary strains $\varepsilon_{t, o}$ were assumed, however for beam $\mathrm{P} 3-1 \mathrm{Kk}$ of the first series and beam P1-2Pk of the third series $\varepsilon_{t, o}$ were not defined. Fig 6 also contains data points (shown by circles) of the previous analysis [24] of 16 beams tested by Clark and Speirs [5]. These beams were reinforced with deformed bars and had different reinforcement ratios and bar diameters. Curve fitting performed by MATLAB for points in Fig 6 corresponding to data of beams reinforced with deformed bars resulted in the following relationship:

$$
\begin{gathered}
\beta=32.8-27.6 p+7.12 p^{2} \\
(\beta=5, \text { if } p \geq 2 \%)
\end{gathered}
$$

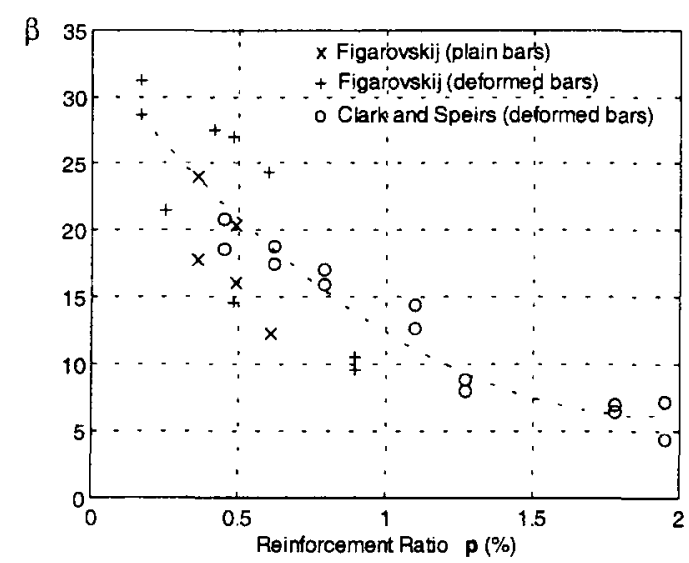

Fig 6. Relationship between reinforcement ratio $p(\%)$ and parameter $\beta$

As it is clearly indicated in Fig 6, values of parameter $\beta$ for beams reinforced with plain bars on average are smaller than for beams with deformed bars. Since Fig 6 contains data of only five beams reinforced with plain bars (reinforcement percentage interval from 0.36 to $0.61 \%$ ), more experimental data of comprehensive tests are needed for drawing up any practical conclusions.

A particular feature of the computed $\sigma_{t}-\varepsilon_{t}$ relations shown in Figs 4 and 5 is that some of them have significant portions of negative stresses. If the possibility of moment-strain measurement errors is excluded, this can be explained by the following: a) the assumption of perfect bond between tensile reinforcement and concrete is not accurate. Reinforcement slippage may occur at advanced stress-strain states, particularly for beams reinforced with bars of larger diameters. Such beams have relatively small total bar perimeter and respective bond surface leading to larger bond stresses. The reinforcement slippage is accompanied by increase in curvature. Calculation of strains and the resultant force of the tensile reinforcement from this curvature using the assumption of linear strain distribution within the section depth gives overestimated values which in equilibrium have to be compensated by decreased (even negative) stresses of the tensile concrete; b) due to shrinkage, significant tensile concrete stresses were already present prior to the test. Therefore, the ascending branch of the calculated $\sigma_{t}-\varepsilon_{t}$ relationship had a missing part of initial stresses corresponding to the shrinkage stresses. With the shorter ascending branch, the zero point moves up and the descending branch enters the negative stress zone; $c$ ) assumption of the constant $\sigma_{t}-\varepsilon_{t}$ diagram for all tensile concrete fibres is inaccurate. As it was described earlier, the $\sigma_{t}-\varepsilon_{t}$ diagram is computed for the extreme fibres assuming that other fibres follow the same law. At the initial cracking stages, the computed $\sigma_{t}-\varepsilon_{t}$ curve actually represents average stresses of the fibres close to the extreme surface and reinforcement. An extreme fibre at an average strain $\tilde{\varepsilon}_{t}>\varepsilon_{c r}$ carries some average stress $\tilde{\sigma}_{t}$. It is assumed that a tensile fibre distant from the reinforcement also carries $\tilde{\sigma}_{t}$ when the strain in that fibre reaches $\tilde{\varepsilon}_{t}$. However, this can not be true, because distant fibres are less affected by bond with reinforcement and, therefore, carry lesser stresses. When equilibrium equations are solved, in order to compensate for these increased stresses, stresses in the extreme fibre are reduced what in some cases might lead to negative stresses.

Analysis has shown that $\sigma_{t}-\varepsilon_{t}$ curves for members with higher reinforcement ratios have little effect on the curvature and deflection calculation. Therefore, the nega- 
tive stress portions of $\sigma_{t}-\varepsilon_{t}$ diagrams can be simply excluded. Besides, the negative stress parts can be reduced or even eliminated if shrinkage effects are assessed.

Previous analysis [24] has shown that the phenomenon of the negative stress portions is more common for beams having higher reinforcement ratios. However, a $\sigma_{t}-\varepsilon_{t}$ curve has a reduced effect on curvatures for members with higher reinforcement ratios. Therefore, the negative portions of the curves can be simply excluded.

\section{A new constitutive relationship for cracked tensile concrete in flexure}

The stress-strain relationships for tensile concrete obtained from beam tests of Clark and Speirs [5] and Figarovskij [38], see Figs 4 and 5, have been used for derivation a new constitutive relationship. From a number of fitting curves considered, as a compromise between accuracy and simplicity, the following shape for the descending part of the $\sigma_{t}-\varepsilon_{t}$ relationship shown in Fig 7 has been proposed:

$$
\sigma_{t}=a \sigma_{c r}\left(1-\frac{\overline{\varepsilon_{t}}}{\beta}-\frac{1+\beta(1-a) / a}{\beta\left(\overline{\varepsilon_{t}}\right)^{b}}\right),
$$

where

$$
\overline{\varepsilon_{t}}=\frac{\varepsilon_{t}}{\varepsilon_{c r}} ; \varepsilon_{c r}=\frac{\sigma_{c r}}{E_{c}} .
$$

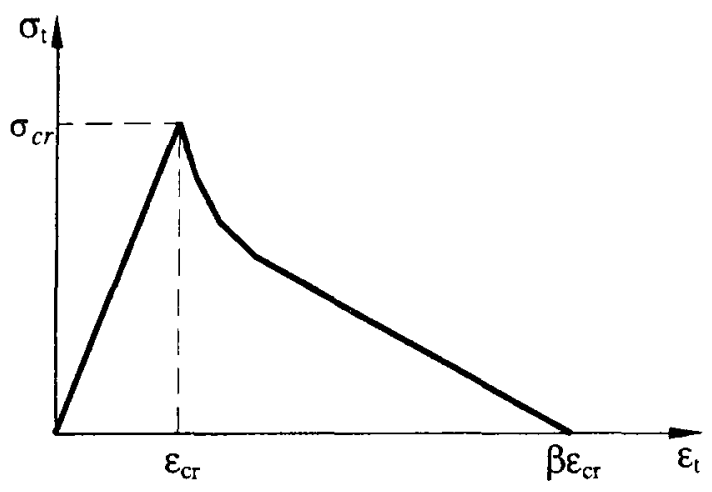

Fig 7. Stress-strain relationship for tensile concrete in flexure

Due to present state of knowledge, parameters $a$ and $b$ have been assumed as 0.625 and 1 respectively. Then Eq (9) acquired the following shape:

$$
\sigma_{t}=0.625 \sigma_{c r}\left(1-\frac{\overline{\varepsilon_{t}}}{\beta}-\frac{1+0.6 \beta}{\beta \overline{\varepsilon_{t}}}\right) .
$$

Parameter $\beta$ characterising the length of the descending branch of the $\sigma_{t}-\varepsilon_{t}$ curve (see Fig 7) is equal to such $\overline{\varepsilon_{t}}$ which corresponds to zero stress. Parameter $\beta$ is taken from Eq (8) and $\sigma_{c r}$ and $E_{c}$ if absent can be assessed from Eqs (6) and (7) respectively.

\section{Concluding remarks}

The present research is dedicated to investigation of tension stiffening effect in lightly reinforced concrete beams using short-term experimental data reported in literature. Applying the method developed by the author and his co-workers, average stress-strain relationships for cracked tensile concrete have been derived for beams reinforced with plain and deformed bars. In general, results of this analysis fitted within the trends set by the earlier work [24]. It has been shown that the shape of the relationships mostly depend on reinforcement ratio and surface of reinforcement bars. The length of the descending branch of the curves reflecting the tension stiffening effect was considerably more pronounced for beams with smaller reinforcement ratios. Use of deformed bars in the tensile zone also secured greater tension stiffening. Based on these and previously obtained stress-strain curves, a new constitutive relationship for tensile concrete in flexure has been proposed. The relationship in a simplified integrated manner takes into account complex effects of cracking, bond and shrinkage. This constitutive model can be applied not only in a finite element analysis, but also in a simple iterative technique based on classical principles of strength of materials extended to layered approach. The latter technique as a universal, simple and accurate tool can serve as an alternative to the code methods.

\section{References}

1. Considere. Influence des armatures metalliques sur le properietes des mortiers et beton. (Influence of Metal Reinforcement on the Properties of Mortar and Concrete) // Le Genie Civil, Vol 34, No 15, 1899, p. 229-233.

2. E. Mörsch. Concrete-Steel Construction. New Yourk: McGraw Hill, 1909.

3. W. C. Schnobrick. The Role of Finite Element Analysis of Reinforced Concrete Structures // Finite Element Analysis of Reinforced Concrete Structures: Proceedings of the Seminar sponsored by the Japan Society for the Promotion of Science and US National Science Foundation. Published by ASCE, Tokyo, Japan, May 21-24, 1985, p. 1-24.

4. P. S. Rao and B. V. Subrahmanyam. Trisegmental MomentCurvature Relations for Reinforced Concrete Members // 
Proceedings of the American Concrete Institute. Vol 70, No 5, May 1973, p. 346-351.

5. A. Clark and D. M. Speirs. Tension Stiffening in Reinforced Concrete Beams and Slabs under Short-Term Load. Technical Report No 42.521, Cement and Concrete Association, London, $1978.20 \mathrm{p}$.

6. R. I. Gilbert and R. F. Warner. Tension Stiffening in Reinforced Concrete Slabs // J. Struct. Div. ASCE, 104(12), 1978, p. 1885-1900.

7. A. K. Gupta and S. R. Maestrini. Tension Stiffness Model for Reinforced Concrete Bars // J. Struct. Engrg., ASCE, 116(3), 1990, p. 769-790

8. F. J. Vecchio and M. P. Collins. The Modified Compression Field Theory for Reinforced Concrete Elements Subjected to Shear // J. Amer. Concrete Inst., 83(2), 1986, p. 219-231.

9. B. Massicotte, A. E. Elwi and J. G. MacGregor. Tension stiffening model for planar reinforced concrete members // Journal of Structural Engineering, ASCE, 1990, 116, No 11, p. 3039-3058.

10. G. Gajer and P. F. Dux. Crack Band Based Model for FEM Analysis of Concrete Structures // Journal of Structural Engineering, ASCE, V. 116, No 6, 1990, p. 1696-1714.

11. W. H. Gerstle, P. P. Dey, N. N. V. Prasad, P. Rahulkumar, and $M$. Crack Growth in Flexural Members - A Fracture Mechanics Approarch // ACI Struct. J., 89(6), 1992, p. 617625 .

12. S. Balakrishnan and D. W. Murray. Concrete Constitutive Model for NLFE Analysis of Structures // J. Struct. Engtg., ASCE, 114(7), p. 1449-1466.

13. T. T. C Hsu. Unified Theory of Reinforced Concrete, CRC Press, Inc., 1993, $336 \mathrm{p}$.

14. M. A. Polak and K. G. Blackwell. Modeling Tension in Reinforced Concrete Members Subjected to Bending and Axial Load // Journal of Structural Engineering, ASCE. September, 1998, p. 1018-1024.

15. F. J. Vecchio and M. P. Collins. Response of Reinforced Concrete to In-Plane Shear and Normal Stresses. Publication No 82-03, Department of Civil Engineering, University of Toronto, 1982, $332 \mathrm{p}$.

16. X. B. Pang and T. T. C. Hsu. Behavior of Reinforced Concrete Membrane Elements in Shear // ACl Structural Journal, V. 92, No 6, Nov.-Dec. 1995, p. 665-679.

17. A. Scanlon and D. W. Murray. Practical Calculation of Two Way Slab Deflection. Concrete Int., Vol 4, No 11, 1982, p. $43-50$.

18. S. C. Lin and A. C. Scordelis. Nonlinear Analysis of RC Shells of General Form // J. Struct. Div., ASCE, 101(3), 1975, p. 523-538.

19. A. Vebo and A. Ghal. Moment-Curvature Relation of Reinforced Concrete Slabs // J. Struct. Div., ASCE, 103(3), 1977, p. 515-531.

20. F. Damjanic and D. R. J. Owen. Practical Considerations for Modelling of Post-cracking Concrete Behaviour for $\mathrm{Fi}$ nite Element Analysis of Reinforced Concrete Structures // Proceedings, International Conference on Computer Aided Analysis and Design of Concrete Structures, Swansea: Pineridge Press, 1984, p. 693-706.

21. G. A. Mehlhorn. Calculation for Reinforced Concrete Beams under Bending and Torsion using Three-Dimensional Finite Elements// IABSE Colloquim on Advanced Mechanics of Reinforced Concrete, Delft, Final Report. June 1981, p. 591-601
22. R. J. Cope. Nonlinear Analysis of Reinforced Concrete Slabs // Computer Modelling of RC Structures, Swansea: Pineridge Press, 1986, p. 3-43

23. D. J. Careira and K. -H. Chu. Stress-Strain Relationship of Reinforced Concrete in Tension // ACI Journal, 83(1), 1986, p. 21-28.

24. G. Kaklauskas, J. Ghaboussi, and X. Wu. Neural Network Modelling of Tension Stiffening Effect for R/C Flexural Members // Proceedings, EURO-C 1998-Computational Modelling of Concrete Structures, Badgastein, Austria, March 31 - April 3, 1998, p. 823-832.

25. A. Williams. Tests on Large Reinforced Concrete Elements Subjected to Direct Tension. Technical Report No 42.562. London: Cement and Concrete Association, 1986. 56 p.

26. E. Wollrab, S. M. Kulkarni, C. Ouyang and S. P. Shah Response of Reinforced Concrete Panels under Uniaxial Tension // ACI Structural Journal, November-December 1996, p. 648-657.

27. L. A. Clark and W. B. Cranston. The Influence of Bar Spacing on Tension Stiffening in Reinforced Concrete Slabs / Proceedings, International Conference on Concrete Slabs, Dundee, 1979 , p. 118-128.

28. M. A. Polak and D. T. Killen. The Influence of the Reinforcing Bar Diameter on the Behavior of Members in Bending and In-Plane Tension // ACI Structural Joumal, V. 95, No 5, Sep.-Oct. 1998, p. 471-479.

29. G. K. V. Prakhya and C. T. Morley. Tension Stiffening and Moment-Curvature Relations for Reinforced Concrete Elements // ACI Journal, 87(5), 1990, p. 597-605.

30. A. Hilleborg. The Influence of Tensile Toughness of Concrete on the Behaviour of Reinforced Concrete Structures // Proceedings, 9th FIP Congress (Stockholm, 1982), Federation Internationale de la Precontrainte, Wexham Springs, V. 1, 1982, p. $157-164$.

31. G. C. Sih and A. DiTommaso. Editors Fracture Mechanics of Concrete: Structural Application and Numerical Calculation, Martinus Nijhoff Publishers, Dordrecht, 1985, 276 p.

32. P. E. Petersson and P. J. Gustavasson. Numerical Methods in Fracture Mechanics, Pineridge Press, Swansea, 1980, p. 707-719.

33. Z. P. Bazant and B. Oh. Crack Band Theory for Fracture of Concrete // Mat. and Structs., (Materiaux et Constructions), 16(93), 1983, p. 155-177.

34. P. Nallathambi, B. L. Karihaloo, and B. S. Heaton. Effect of Specimen and Crack Sizes, Water/Cement Ratio and Coarse Agregate Texture upon Fracture Toughness of Concrete // Magazine of Concrete Research (London), V. 36, No 129 , Dec. 1984, p. 227-236.

35. P. Z. Bazant and P. B. Oh. Numerical Simulation of Progressive Fracture in Concrete Structures: Recent Developments // Proceedings, International Conference on Computer Aided Analysis and Design of Concrete Structures, Pineridge Press, Swansea, 1984, p. 1-18.

36. G. Kaklauskas, J. Ghaboussi and N. M. Hawkins. Determination of Stress-Strain Curves for Concrete from RC Beam Tests // Proceedings, Fifth Int. Conf. Modem Building Materials and Techniques, Vilnius, Lithuania, May 21-24, 1997, Vol 1. V.: Technika, 1997, p. 138-145.

37. G. Kaklauskas. A Technique for Investigation of Tension Stiffening Effect of Flexural RC Members // Proceedings, 10th Nordic Seminar on Computational Mechanics, Tallinn, Estonia, October 24-25, 1997, p. 228-231. 
38. V. V. Figarovskij. Experimental Investigation of Stiffness and Cracking of Reinforced Concrete Flexural Members Subjected to Short-Term and Long-Term Loading (in Russian). Moscow: PhD Thesis, 1962.

Iteikta 19991027

\section{NAUJA SUPLEIŠÉJUSIO TEMPIAMO BETONO ITEMPIU-DEFORMACIJU PRIKLAUSOMYBÉ LENKIAMIEMS ELEMENTAMS}

\section{G. Kaklauskas}

\section{Santrauka}

Straipsnyje pasiūlyta nauja supleišejusio tempiamo betono itempių-deformacijų priklausomybé lenkiamų gelžbetoninių elementų deformacijoms skaičiuoti. Taikant šią priklausomybę, lenkiamu elementų deformacijos gali būti apskaičiuojamos tiek baigtinių elementu metodu, tiek klasikinèmis medžiagu atsparumo formulèmis, skerspjūvị sudalijus i betono ir armatūros sluoksnius. Ivade pateikta plati supleišejusio tempiamo betono itempių-deformaciju priklausomybių [4-35] apžvalga.

Kuriant medžiagos priklausomybę, buvo taikomas autoriaus ir jo kolegu pasiūlytas metodas [24, 37], kuriuo iš eksperimentiniu lenkiamı gelžbetoninių siju momentų-kreiviц ir (arba) momentų-deformaciju diagramu nustatoma visa tempiamo betono vidutiniu itempiu-deformaciju diagrama, iskaitant ir jos krintanciaja dali.

Šiame darbe tempiamo betono vidutinių itempiu-deformacijų kreives buvo nustatytos 16 mažai ir vidutiniškai armuotu stačiakampio skerspjūvio gelžbetoninių sijų kurias trumpalaike apkrova (dviem koncentruotomis jègomis) išbandè Figarovskis
[38]. Darbe panaudoti pirmosios ir trečiosios serijos siju (1 lentelè), armuotų atitinkamai lygia ir rumbuota armatūra, duomenys. Iš eksperimentinių momentų-kreivių diagramų ( 2 ir 3 pav.) nustatytos tempiamo betono vidutinių itempiu-deformaciju priklausomybés pateiktos 4 ir 5 pav. Šių kreivių krintančioji dalis charakterizuoja supleišejusio betono darbą. Nors kreivių forma skirtingoms sijoms yra pakankamai panaši, kreives labiausiai skiriasi krintanciosios dalies ilgiu. Krintančioji kreives dalis charakterizuojama deformacija $\varepsilon_{t, 0}$, atitinkančia jtempius, lygius nuliui. Šios deformacijos, išreikštos santykiniu dydžiu $\beta=\varepsilon_{t, 0} / \varepsilon_{c r}$ (kur $\varepsilon_{c r}$ yra betono supleišejjimo deformacija, žr. 1 pav.), priklausomybè nuo armavimo procento yra pateikta 6 pav. Šiame paveiksle kartu pateikti ankstesnių tyrimu rezultatai, gauti Clarko ir Speirso eksperimentinems sijoms [5]. Akivaizdi $\beta$ priklausomybé nuo armavimo procento $p$ (6 pav.) aprašoma (8) priklausomybe. Apdorojus šiame darbe bei anksciau gautas tempiamo betono itempiu-deformaciju diagramas, buvo pasiūlyta minètoji medžiagos priklausomybè, aprašyta (9) arba (11) lygtimi.

Gintaris KAKLAUSKAS. PhD, Senior Researcher and Associate Professor. Dept of Reinforced Concrete Structures, Vilnius Gediminas Technical University, Saulëtekio al. 11, 2040 Vilnius, Lithuania.

Graduate of Vilnius Civil Engineering Institute (presently Vilnius Gediminas Technical University, VGTU), 1982 (civil engineer). $\mathrm{PhD}$ (1990). Research visits: Aalborg University (Denmark, 1991), University of Glamorgan (UK, 1994/1995, 1998), University of Illinois, Urbana-Champaign (USA, 1996). Author and co-author of 2 monographs, 1 invention and a number of papers. Research interests: development of constitutive relationships for concrete and numerical simulation of reinforced concrete structures. 